\title{
Alagille Syndrome Mimicking Biliary Atresia Confirmed by Jagged1 (JAG1) Gene Analysis in a Newborn: A Case Report
}

Hui Jeong Yun, M.D., Chul Jun Cho, M.D., Yong Wook Kim, M.D., Eun Young Kim, M.D., Hyung Min Cho, M.D., Young Kim, M.D., Hae In Jang, M.D., and Kyoung Sim Kim, M.D.

Department of Pediatrics, Kwangju Christian Hospital, Gwangju, Korea

\section{ABSTRACT}

Alagille syndrome is a complex autosomal dominant disorder secondary to defects in the Notch signaling pathway, primarily caused by mutations in the Jaggedl (JAG1) gene. The liver, heart, skeleton, face and eyes are the body parts most commonly involved. Alagille syndrome may mimic other causes of high gamma-glutamyl transferase (GGT)-linked cholestasis, most notably biliary atresia in the neonatal period. Infants with Alagille syndrome are occasionally misdiagnosed as cases with biliary atresia due to variations in clinical features that might be expressed in early infancy. We describe a case of Alagille syndrome mimicking biliary atresia, identified by sequencing analysis of the JAG1 gene in a newborn. During counseling, family members of the patient have also been found to demonstrate various phenotypes and levels of disease severity of Alagille syndrome.

Key Words: Alagille syndrome, Biliary atresia, Cholestasis

\section{서론}

Alagille 증후군은 간내 담도 형성 부전으로 인한 만성 담즙정체, 심혈관계 이상, 골격계 이상, 눈의 이상, 특징적인 얼굴 모양 등을 주요 증상으로 하는 상염색체 우성 유전 질환으로 30,00050,000 명에 1명꼴로 발생한다 ${ }^{1,2)}$. 임상적으로 Alagille 증후군으로 진단된 환자의 약 $94 \%$ 에서 Jagged1 (JAG1) 유전자 돌연변이가 확인되었으며, 약 1.5\%에서 NOTCH2 유전자 돌연변이가 확 인되었다 ${ }^{3)}$. 이들 유전자는 여러 기관(organ)의 배아 발생(embryogenesis)을 조절하는 Notch 신 호전달 체계(Notch signaling pathway)와 연관되어 있다고 알려져 있다 ${ }^{4,5)}$.

신생아 시기에 발현되는 Alagille 증후군의 초기 증상은 황달, 회색 변, 진한 소변 등 담즙정체 에 의한 증상이 대부분이다. 이는 담즙정체증을 유발하는 다른 원인들과의 공통적인 임상 양상 으로 정확한 감별진단이 필요하다. 특히, 담도 폐쇄증(biliary atresia)은 신생아 담즙정체증의 가 장 흔한 원인으로, 치료하지 않을 경우 결국 2 세 이내에 사망하게 되며 생후 2 개월 이내의 수술이 예후에 영향을 미치기 때문에 빠르고 정확한 진단이 중요하다 ${ }^{6,7}$.
Received: 29 June 2017

Revised: 7 August 2017

Accepted: 8 August 2017

Correspondence to: Kyoung Sim

Kim

Department of Pediatrics, Kwangju Christian Hospital, Yangnim-ro 37, Namgu, Gwangju 61661, Korea

Fax: +82-62-650-5040

Tel: +82-62-650-5045

E-mail: kskim000@naver.com

This case was presented as a poster presentation at the $28^{\text {th }}$ annual autumn meeting of the Korea Society of Perinatology.

Copyright(c)

By Korean Society of Neonatology.

All right reserved.

This is an Open-Access article distributed under the terms of the Creative Commons Attribution Non-Commercial License (http://creativecommons.org/licenses/ by-nc/4.0), which permits unrestricted non-commercial use, distribution, and reproduction in any medium, provided the original work is properly cited. 
저자들은 생후 7일째 회색 변과 진한 소변을 주소로 내원하여 초 기 진단 시 담도 폐쇄증으로 오인된 신생아에서, 면밀한 임상적 진찰 과 주의 깊은 가족력 문진을 통해 신속한 유전자 검사를 진행함으로 써 생후 한 달째 Alagille 증후군을 진단하여 침습적 검사 및 불필요 한 수술을 피한 사례를 경험하였기에 이를 보고하는 바이다.

증례

환자: 7일, 여자

주소: 회색 변과 진한 소변

출생력: Para 4-1-0-5인 40세 산모에게서 재태 연령 $36^{+3}$ 주, 출생체 중 $2,720 \mathrm{~g}$ (50 percentile)으로 질식 분만으로 본원 산부인과에서 출

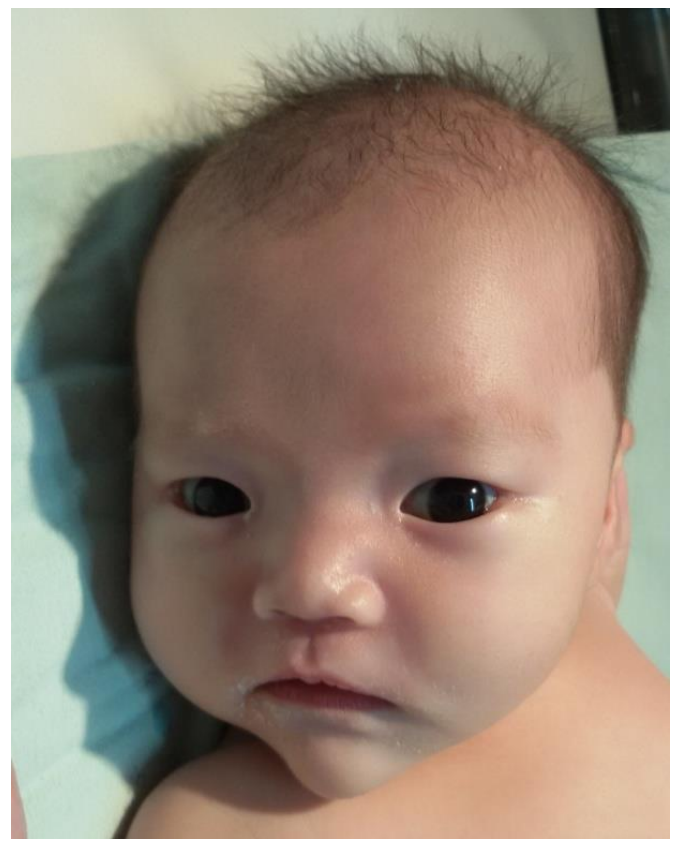

Figure 1. Dysmorphic features of the patient show prominent forehead, deep-set eyes with moderate hypertelorism, small pointed chin and saddle with a bulbous tip.
생하였다. APGAR score는 1분 9점, 5분에 10점이었으며, 분만상 특 이 소견은 없었다.

진찰 소견 및 검사 소견: 양호한 전신 상태로, 넓고 두드러진 이마, 약간의 양안 격리증이 있는 깊은 눈, 작고 뾰족한 턱의 특징적인 얼 굴 모습을 보였으며(Figure 1), 청진 소견상 수축기 심잡음이 좌측 흥 골 상연에서 들렸다. 복부는 부드럽고, 간이나 비장은 촉지되지 않 았다. 출생 당일 말초혈액 검사상 헤모글로빈 $14.9 \mathrm{~g} / \mathrm{dL}$, 헤마토크 릿 40\%, 아스파트산 아미노기전달효소(aspartate aminotransferase, AST) $23 \mathrm{IU} / \mathrm{L}$, 알라닌 아미노기전달효소(alanine aminotransferase, ALT) $5 \mathrm{IU} / \mathrm{L}$, 총 빌리루빈 $1.7 \mathrm{mg} / \mathrm{dL}$ 였다.

생후 7일째 신생아 집중 치료실에 입원하여 시행한 간 기능 검사 에서는 총 빌리루빈 $6.4 \mathrm{mg} / \mathrm{dL}$, 직접 빌리루빈 $1.3 \mathrm{mg} / \mathrm{dL}$ 으로 포 합성 고빌리루빈혈증(conjugated hyperbilirubinemia)을 확인하였 고, 알칼라인 포스피타제(alkaline phosphatase, ALP) 296 IU/L, 감 마-글루타밀 전이효소(gamma-glutamyl transferase, GGT) 407 U/ L, AST 21 IU/L, ALT 9 IU/L로, ALP, GGT의 상승 소견 관찰되어 폐쇄 성 담즙정체성 질환을 의심할 수 있었다(Table 1). 직접 및 간접 쿰스 (coombs) 검사, TORCH panel 결과는 음성이었으며, 신생아 선천성 대사 이상 59종 검사는 정상이었다. 4시간 이상 금식 상태에서 시행 한 복부 초음파에서는 수축되어 있는 담낭을 확인하였으며, 담도 확 장 등의 소견은 없었다(Figure 2A). 생후 15 일째 Phenobarbital 전 처 치 후 시행한 99mTc diisopropyliminodiacetic acid (DISIDA) 간 담 도 조영술에서는 24 시간 후 장관 내 조영제 배출이 보이지 않아 담 도 폐쇄증을 시사하였다(Figure 2B). 간 담도 조영술의 낮은 특이도 를 고려하여, 담도 폐쇄증의 확진을 위한 간 생검 등의 침습적인 검 사를 시행하기로 하였다. 하지만, 생화학적 간 기능 검사 결과 및 영 상학적 검사 결과를 토대로 신생아 시기에 담즙정체증으로 나타날 수 있는 원인을 조사하던 중, 환자의 특징적인 얼굴 생김새와 관련된 Alagille 증후군을 의심하여 다양한 임상 소견에 대해 먼저 검토해 보 았다. 그 결과, 흥부 X-선 검사에서 나비 모양의 척추를 관찰할 수 있 었으며(Figure 3), 심장 초음파 검사상 폐동맥 협착과 심방 중격 결손 을 발견하였다. 추가로 시행한 안과 검사에서는 후태생환(posterior embryotoxon)은 관찰되지 않았으나, 시각 유발 전위 검사에서 Peak

Table 1. Liver Function Test Results

\begin{tabular}{|c|c|c|c|c|c|}
\hline & 7 days after birth & 11 days after birth & 25 days after birth & 28 days after birth & At 3 month \\
\hline AST/ALT (IU/L) & $21 / 9$ & $22 / 13$ & $23 / 15$ & - & $199 / 127$ \\
\hline GGT (U/L) & 407 & 204 & 159 & - & 888 \\
\hline $\mathrm{SB}(\mathrm{T} / \mathrm{D})(\mathrm{mg} / \mathrm{dL})$ & $6.4 / 1.3$ & $5.1 / 1.6$ & $2.4 / 1.6$ & $2.3 / 1.7$ & $5.8 / 5.2$ \\
\hline $\operatorname{Albumin}(\mathrm{g} / \mathrm{dL})$ & 3.9 & 4.1 & 3.8 & - & - \\
\hline
\end{tabular}

Abbreviations: AST, aspartate transaminase; ALT, alanine transaminase; GGT, gamma-glutamyl transferase; ALT, alkaline phosphatase; SB, serum bilirubin; T, total; D, direct; PT, prothrombin time. 


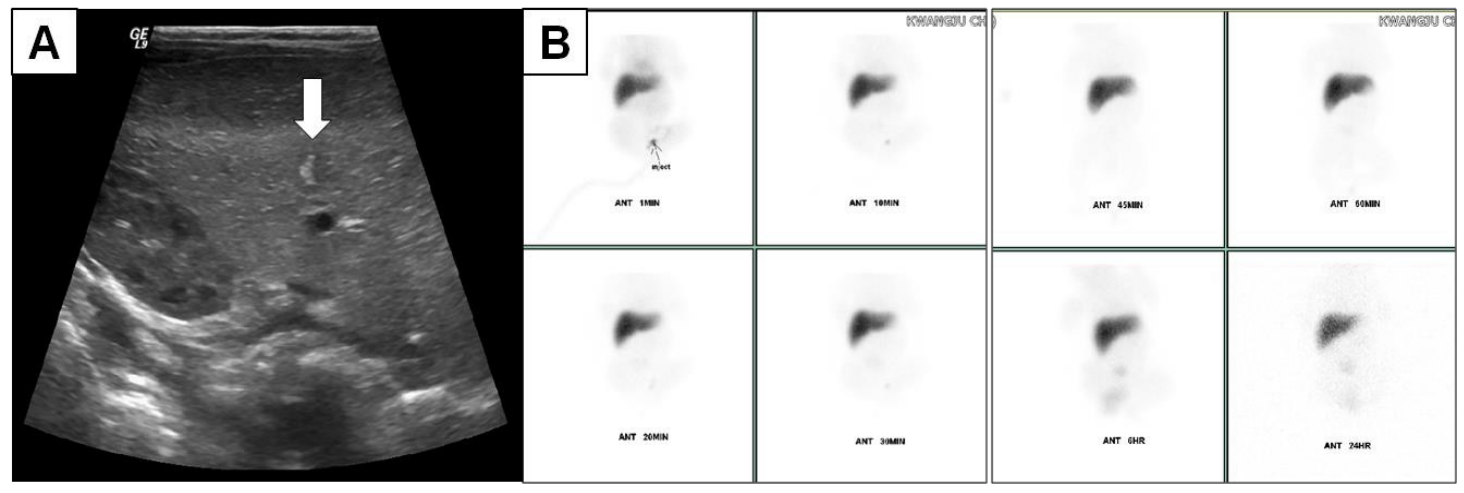

Figure 2. (A) Abdominal sonography shows collapsed gallbladder (arrow). (B) Hepatobiliary scintigraphy shows relatively good hepatic uptake with no evidence of excretion into the bowel at 24 hours.

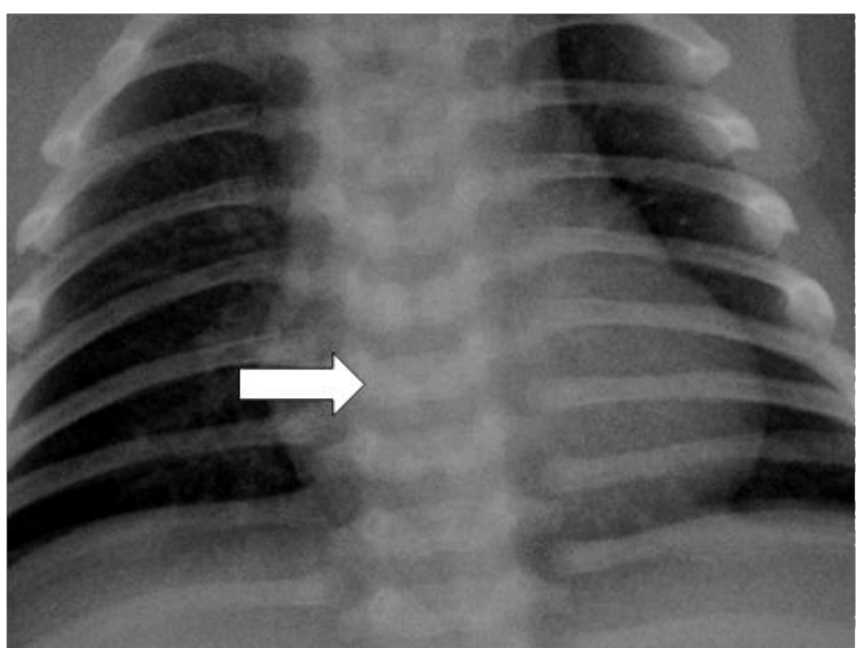

Figure 3. Chest X-ray shows multiple butterfly vertebral bodies (arrow).

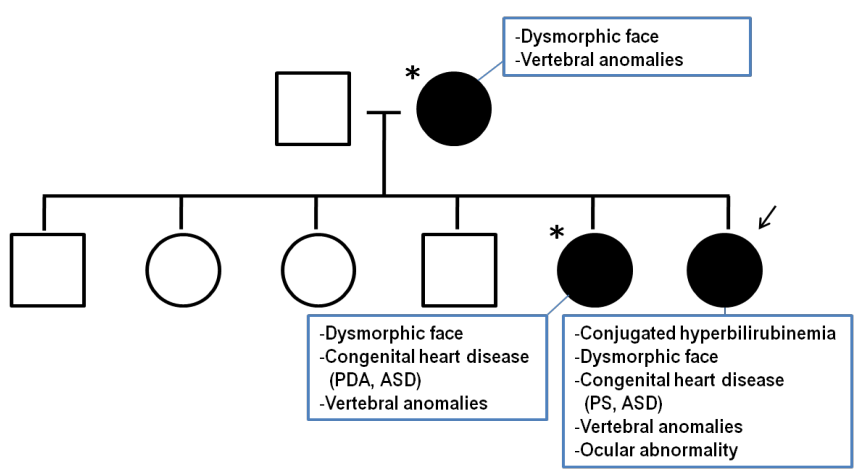

Figure 4. Patient's pedigree shows the family members relevant to Alagille syndrome have various phenotypes and levels of disease severity. The arrow indicates a proband of the patient. The patient's mother and sister are indicated by asterisks.

$100 \mathrm{~ms}$ 에서 양쪽 모두 자극되지 않는 결과를 보였다. 뇌 자기공명 영 상(magnetic resonance imaging, MRI) 검사에서는 이상 소견은 없었 다. 이와 동시에 환자 가족들에 대한 자세한 문진이 진행되었다. 얼
굴 모양을 관찰하고, 선천 심장 병력, 황달 병력 등에 대한 가족력을 조사하였다. 보호자 동의를 얻어 흥부 X-선 사진 등의 검사 자료를 포함한 진료 기록에 대해서도 점검을 진행하였다. 환자의 엄마와 4 살 위 언니 역시 특징적인 얼굴 모습을 보였으며, 흥부 X-선 사진에 서의 나비 모양의 척추를 발견할 수 있었다. 또한 환자의 언니는 본 원에서 시행한 심장 초음파에서 심실 중격 결손 및 동맥관 개존증이 있다는 사실을 확인하였다. 질병 가계도를 작성해 봄으로써, 환자 가 족 내에서 상염색체 우성 유전 질환인 Alagille 증후군의 다양한 표현 형과 질병의 중증도를 관찰해 볼 수 있었다(Figure 4). 생후 20 일째 분자 유전학적 진단을 위해 Alagille 증후군의 원인 유전자인 JAG1 돌연변이 유무에 대한 염기서열 분석을 시행하였다. 분석 결과, 엑손 (exon) 4에서 c.473C>A (p.Ser158Ter) 돌연변이가 발견되었다(Fig ure 5). 염색체 microarray 검사 이상은 없었다. 저자들은 침습적인 추가 검사 진행 없이, 담즙정체, 심혈관계 이상, 골격계 이상, 눈의 이 상, 특징적인 얼굴 등의 전형적인 임상증상을 지닌 유전자 JAG1 돌 연변이가 확인된 Alagille 증후군으로 생후 30 일째 진단하였으며, 더 나아가 환자 가족들에게 유전 질환에 대한 상담을 제공할 수 있었다.

임상경과 및 치료: 환자는 지용성 비타민 공급과 함께 medium chain triglycerides (MCT) 함유 특수 분유로 고열량 식이를 하면서 생 후 한 달 뒤 퇴원하였다. 생후 3개월째 AST $100 \mathrm{IU} / \mathrm{L}, \mathrm{ALT} 127 \mathrm{IU} / \mathrm{L}$, GGT $888 \mathrm{U} / \mathrm{L}, \mathrm{ALP} 530 \mathrm{IU} / \mathrm{L}$ 으로 지속 상승 소견 및 심장 초음파 추 적 검사 결과 $65 \mathrm{mmHg}$ 압력차의 폐동맥 협착 보여 심장 중재 시술 및 간 기능 평가 위해 3 차 병원으로 전원되어 추적 관찰 중이다.

\section{고찰}

1987년 Alagille 등 ${ }^{8)}$ 에 의해 제시된 Alagille 증후군의 진단 기준은 간 생검에서 담도 부족증(bile duct paucity)을 보이면서 다음과 같 은 주요 증상 중 3 개 이상을 동반하는 임상적 기준에 기반을 두고 있 다. 주요 증상으로는 담즙정체, 선천 심장병의 증거, 골격 이상(주로 

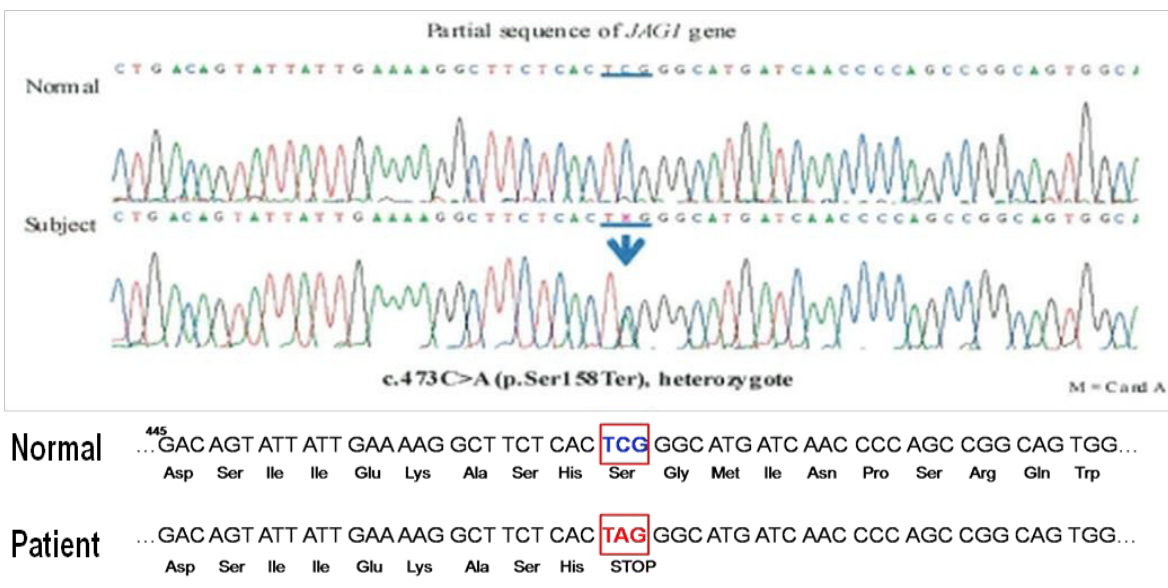

Figure 5. Sequencing analysis of the JAG1 gene shows a heterozygous mutation: c.473C $>$ A (p.Ser158Ter).

나비 모양의 척추), 안과적 이상(주로 후태생환, posterior embryotoxon), 그리고 특징적인 얼굴 모양(높고 넓은 이마, 간격이 넓고 깊은 눈, 특출나고 뾰족한 턱) 등이다. 분자유전학적 진단 방법이 발전함 에 따라 위의 주요 증상 외에도 다양한 임상 증상의 관련성이 밝혀지 면서, 임상증상이 1개 이상이면서 JAG1 또는 NOTCH2 유전자 돌연 변이 검사 양성, 혹은 가족력이 있으면서 2 개의 주요 임상 소견이 있 으면 진단할 수 있도록 폭이 넓어지고 있다 ${ }^{9-11)}$.

보통 생후 3개월 이내에 발현되는 Alagille 증후군의 임상 증상은 담즙정체증으로 발생하는 황달, 무담즙 변, 진한 소변 등이다. 이 시 기에는 담도 폐쇄증과 같은 빠른 수술적 치료가 필요한 질환에 대한 신속한 진단이 중요하므로, 간 초음파와 간 담도 조영술에서도 담도 폐쇄증이 의심되는 경우에는 폐쇄성 담즙정체증을 발생시키는 다른 원인들과의 감별을 위해 간 생검을 시행하게 된다.

간 생검이 상당히 신뢰성 있는 검사라고 하지만, 침습성이 있으며 담도 폐쇄증의 조직학적 소견이 담즙정체를 일으키는 신생아 간염 등 다른 질환에서도 유사하게 보이는 경우가 있어서 문제가 되고 있 다 $^{12)}$. 특히, Alagille 증후군의 특징적인 조직 소견이 생후 9주 이후에 야 나타나고, Alagille 증후군이 있는 6개월 미만의 일부 영아에서는 간 생검에서 담도 폐쇄증의 특징적인 소견인 담관의 증식(ductular proliferation)이 관찰되어 오히려 이른 시기의 간 생검은 진단적 혼 란을 가중시킬 수 있다고 보고되고 있다 ${ }^{13,14)}$. 또한, 담도 부족증(bile duct paucity)이 Alagille 증후군 외에도 다운 증후군, 낭성 섬유증, 선 천성 감염, alpha-1-antitrypsin 결핍증 등의 다양한 질환군에서 나타 날 수 있기 때문에 현재는 간 생검이 Alagille 증후군의 진단에 필수 로 정의되진 않는다 ${ }^{15)}$. 그렇기 때문에 본 증례의 환자와 같이 신생아 시기에 Alagille 증후군과 담도 폐쇄증이 중첩되는 경우에는 분자 유 전학적 검사가 침습적인 간 생검보다 먼저 고려될 수 있다 ${ }^{15,16)}$.

하지만, Alagille 증후군을 지닌 환자에서 담즙정체는 신생아기에 종종 나타나는 반면, 특징적인 얼굴 모양은 출생 시에 알아보기가 어
렵고 2세 전후로 명확해지기 때문에, 조기에 Alagille 증후군을 의심 하기는 쉽지 않다. 실제로 담즙정체와 관련된 임상 증상을 주소로, 생후 이른 시기에 담도 폐쇄증으로 진단된 후 나중에 Alagille 증후 군이 확인된 일부 신생아에서는, 수술 중 담관 조영술을 받고 심지 어 Kasai 수술까지 받는 사례들이 보고되고 있다 ${ }^{13,14,16,17)}$. Kaye 등 ${ }^{13)}$ 과 Lee 등 ${ }^{14)}$ 은 Kasai 수술을 받은 Alagille 증후군의 환자군과 수술을 받지 않은 환자군에 대한 장기간 예후에 관련하여 수술한 군에서 상 대적으로 더 불량한 예후를 지닌다고 발표하였다. 특히, Kaye 등은 Kasai 수술을 받은 환자군에서 수술을 받지 않은 환자군보다간 이식 의 비율이 의미있게 높았다는 결과를 발표하면서, 수술 그 자체가 불 량한 예후에 영향을 줄 수 있음을 강조하였다 ${ }^{13)}$.

신생아나 영아 시기에 Alagille 증후군이 의심되는 환자에 대해 조 기 진단을 하는 것이 환자의 치료와 향후 예후를 위해 중요하다. 이 때 간과하지 말아야 할 점이 바로, 임상 관찰 및 환자 가족력에 대한 주의 깊은 문진이다. 본 증례에서 환자는 담즙정체, 선천 심장병의 증거, 척추기형, 안과적 이상, 특징적인 얼굴 모양의 5 가지 임상적 진 단 기준을 만족하는 전형적인 Alagille 증후군으로 진단할 수 있었다. 하지만, 담즙정체로 인한 임상 증상과 간 기능 검사 및 영상 의학 검 사 결과를 토대로 담도 폐쇄증으로 오인 후 간 생검 및 수술을 시행 하려 하였다. 이후, 환자에 대한 전체적인 신체 검진 및 방사선학적 재평가와 함께 가족력을 살핌으로써 Alagille 증후군에 대해 접근하 였으며, 신속한 분자 유전자 검사로 진단한 사례이다.

신생아에서의 Alagille 증후군의 정확한 진단이 적절한 치료 및 양 호한 예후로 이어질 수 있다는 점에서 담즙정체증을 보이는 신생아 를 접하는 소아과 의사들에게 환자에 대한 세심한 신체 진찰과 환자 가족들에 대한 문진, 필요시 그에 따른 신속한 유전자 검사의 진행이 중요하다고 하겠다. 


\section{REFERENCES}

1) Alagille D, Odièvre M, Gautier M, Dommergues JP. Hepatic ductular hypoplasia associated with characteristic facies, vertebral malformations, retarded physical, mental, and sexual development, and cardiac murmur. J Pediatr 1975;86:63-71.

2) Kamath BM, Bason L, Piccoli DA, Krantz ID, Spinner NB. Consequences of JAG1 mutations. J Med Genet 2003;40:891-5.

3) Kamath BM, Bauer RC, Loomes KM, Chao G, Gerfen J, Hutchinson A, et al. NOTCH2 mutations in Alagille syndrome. J Med Genet 2012;49:138-44.

4) Kamath BM, Spinner NB, Piccoli DA. Alagille syndrome. In: Suchy FJ, Sokol RJ, Balistreri WF, editors. Liver disease in children. 4th ed. New York: Cambridge University Press, 2014:21633.

5) Penton AL, Leonard LD, Spinner NB. Notch signaling in human development and disease. Semin Cell Dev Biol 2012;23:450-7.

6) Bates MD, Bucuvalas JC, Alonso MH, Ryckman FC. Biliary atresia: pathogenesis and treatment. Semin Liver Dis 1998;18:28193.

7) Feldman AG, Sokol RJ. Neonatal cholestasis. Neoreviews 2013; 14:e63-73.

8) Alagille D, Estrada A, Hadchouel M, Gautler M, Odièvre M, Dommergues JP. Syndromic paucity of interlobular bile ducts (Alagille syndrome or arteriohepatic dysplasia): review of 80 cases. J Pediatr 1987;110:195-200.
9) Elmslie FV, Vivian AJ, Gardiner H, Hall C, Mowat AP, Winter RM. Alagille syndrome: family studies. J Med Genet 1995;32:264-8.

10) Mouzaki M, Kamath BM. Alagille syndrome. In: Dhawan A, edi tor. Concise pediatric and adolescent hepatology. Basel: Karger, 2012;50-63. (Pediatr Adolesc Med; vol. 16)

11) Turnpenny PD, Ellard S. Alagille syndrome: pathogenesis, diagnosis and management. Eur J Hum Genet 2012;20:251-7.

12) Shah HA, Spivak W. Neonatal cholestasis: new approach to diagnosis evaluation and therapy. Pediatr Clin North Am 1994; 41:943-66.

13) Kaye AJ, Rand EB, Munoz PS, Spinner NB, Flake AW, Kamath BM. Effect of Kasai procedure on hepatic outcome in Alagille syndrome. J Pediatr Gastroenterol Nutr 2010;51:319-21.

14) Lee HP, Kang B, Choi SY, Lee S, Lee SK, Choe YH. Outcome of Alagille syndrome patients who had previously received Kasai operation during Infancy: a single center study. Pediatr Gastroenterol Hepatol Nutr 2015;18:175-9.

15) Kamath BM, Piccoli DA. Alagille syndrome. In: Murray KF, Horslen S, editors. Diseases of the liver in children: evaluation and management. New York: Springer New York, 2014:227-46.

16) Dědič T, Jirsa M, Keil R, Rygl M, Šnajdauf J, Kotalová R. Alagille syndrome mimicking biliary atresia in early infancy. PLoS One 2015;10:e0143939.

17) Hwang EK, Lee GH, Ryoo E, Cho KH, Kim GH, Lee HS, et al. A case of Alagille syndrome. Korean J Pediatr 1998;41:410-4. 